\section{Vietnam Journal of Agricultural Sciences}

\title{
An Overview of Drug Effects on Bone Healing on Animal Research Models
}

\author{
Nguyen Hoai Nam ${ }^{1} \&$ Naruepon Kampa ${ }^{2}$ \\ ${ }^{1}$ Faculty of Veterinary Medicine, Vietnam National University of Agriculture, Hanoi \\ 131000 , Vietnam \\ ${ }^{2}$ Faculty of Veterinary Medicine, Khon Kaen University, Khon Kaen 40002, Thailand
}

\begin{abstract}
Bone fracture is a common health problem in humans and animals, and the healing of the bone fracture is a complicated process. Several drugs may be used concurrently with the treatment of fractures, but they may interfere with the healing process of the bone. The present research reviewed previously published studies with the objective to enhance the understandings of the effects of different drugs on bone healing. There is clear evidence that antibiotics, corticosteroids, nonsteroidal inflammatory drugs, and chemotherapeutic drugs all affect bone healing. By contrast, the effect of anticoagulants on bone healing is controversial, so more research is needed to determine its efficacy. In addition, there is no direct evidence to approve the effect of anesthetics on bone healing, so this is another area in need of further research.
\end{abstract}

\section{Keywords}

Animal model, bone healing, drug, rat femur

\section{Introduction}

Bone fracture causes harmful effects to patients' health, degrades their quality of life, and is responsible for costly treatments. Annually, millions of musculoskeletal procedures are performed worldwide (Jahangir et al., 2008). Each year, billions of dollars have been spent for the treatments of bone fracture and hip replacement, and the number has been increasing over time. In 2005, more than USD 20 billion was spent on medical care for over 300,000 spinal fusions (Porter et al., 2009). Pathogenic bone defects caused by cancer were responsible for more than 3,000 pediatric hospitalizations, and cost over USD 70 million (Porter et al., 2009).

In animals, about 800,000 pets are involved in vehicle crashes annually in USA (Strickland, 2014). High rise syndrome may cause limb fracture in $46.2 \%$ of fallen cats, of which $38.5 \%$ of fractures are in forelimbs and $61.5 \%$ were in the hind limbs are. Tibiae are most commonly fractured followed by the femur (Vnuk et al., 2004). The treatment cost of bone fractures in companion animals can procure

Correspondence to nguyenhoainam@vnua.edu.vn 
several million Vietnam Dong per case.

Antibiotics, anti-inflammatory drugs and anesthetics are usually used during treatment of bone fracture. Sometimes, anticoagulants or chemotherapy drugs may be applied in orthopaedic animals treatments. All of these drugs may have some effects on the course of bone healing. The pharmacological factors associated with bone healing in humans and animals are similar in many aspects; therefore, understanding these factors is useful and can enhance the successful treatment. This narrative review focuses on the effects of drugs used on the bone healing process based on the information retrieved from an extensive literature review.

\section{Effects of Drugs on Bone Healing}

Prevention and/or treatment of diseases may involve many types of drugs. They can be generally divided into 6 groups including antibiotics, corticosteroids, non-steroidal antiinflammatory drugs (NSAIDs), anticoagulants, chemotherapeutic agents and anesthetics. When used in animals with bone fractures, some of these drugs may interfere with the bone healing process. Tables 1-5 present the effects of such drugs on fracture healing in animal models.

\section{Effects of Antibiotics on Bone Healing}

Many antibiotics have been reported to affect bone healing including quinolones (Gough et al., 1996), ciprofloxacin (Huddleston et al., 2000), levofloxacin and trovafloxacin (Perry et al., 2003), tetracycline (Kim et al., 2004) and cefuroxime (Natividad-Pedreño et al., 2016). Effect of gentamicin on bone healing is controversial. Kim et al. (2004) reported that it decreased bone formation, however, Fassbender et al. (2013) and Haleem et al. (2004) did not find similar results. Cefazolin had no effect on fracture healing parameters including callus mechanical resistance and histological scores (Natividad-Pedreno et al., 2016). Also, vancomycin did not influence biomechanical and radiographic scores of healing bone (Haleem et al., 2004). Interestingly, doxycycline inhibited osteolysis, and is suggested for prevention and treatment of wear particle-induced osteolysis and aseptic loosening (Zhang et al., 2007).

The negative effects of antibiotics on bone healing may be due to their high doses such as $100 \mathrm{mg} / \mathrm{kg} / \mathrm{day}$ for cefuroxime (NatividadPedreno et al., 2016) and ciprofloxacin (Huddleston et al., 2000), $70 \mathrm{mg} / \mathrm{kg} /$ day for trovafloxacin and $50 \mathrm{mg} / \mathrm{kg} /$ day for levofloxacin (Perry et al., 2003), and due to long treatment durations, such as 3-4 weeks (Huddleston et al., 2000; Perry et al., 2003; Natividad-Pedreño et al., 2016). Antibiotics play a pivotal role in prevention and treatment of bacterial infection in many diseases and procedures, especially, orthopedic cases. The use of antibiotics is inevitable as long as their doses and durations are carefully calculated and followed.

\section{Effects of corticosteroids on Bone Healing}

In vivo studies have demonstrated that many corticosteroids including cortisone (Sissons \& Hadfield, 1955), prednisolone (Luppen et al., 2002; Yaghini et al., 2017), prednisone (Bostrom et al., 2000; Waters et al., 2000), methylprednisolone (Xie et al., 2011) and dexamethasone (Sawin et al., 2001) affected the bone healing process. The common aspect of these studies wa that the duration of treatments was prolonged, i.e., 42 days for dexamethasone (Sawin et al., 2001), 56-78 days for prednisolone (Luppen et al., 2002; Yaghini et al., 2017) and 96 days for prednisone (Bostrom et al., 2000; Waters et al., 2000). On the other hand, when used for a shorter duration, i.e., 14-21 days, corticosteroid doses were very high, i.e., $20 \mathrm{mg} / \mathrm{kg} /$ day for methylprednisolone (Xie et al., 2011), and $10-20 \mathrm{mg} / \mathrm{kg} / \mathrm{day}$ for cortisone (Sissons \& Hadfield, 1955). With a similar duration of treatment (21 days) but several times lower doses $(0.5 \mathrm{mg} / \mathrm{kg} /$ day $)$, no significant effect of prednisolone on fracture healing was observed although the numeric values of the mechanical parameters were lower in the treated group (Bissinger et al., 2016). Being used for 4 consecutive days, methylprednisolone at 2 $\mathrm{mg} / \mathrm{kg} / \mathrm{day}$ (Hogevold et al., 1992) and prednisone at $0.02 \mathrm{mg} / \mathrm{kg} / \mathrm{day}$ (Aslan et al., 2005) had no effect on bone healing. 
Table 1. In vivo effects of different antibiotics on bone healing

\begin{tabular}{|c|c|c|c|}
\hline Drug and dosage & $\begin{array}{l}\text { Animal and } \\
\text { bone }\end{array}$ & Results & References \\
\hline $\begin{array}{l}\text { Cefazolin: } 50 \mathrm{mg} / \mathrm{kg} \text { per day, daily for } \\
4 \text { weeks. Cefuroxime: } 100 \mathrm{mg} / \mathrm{kg} \text { per } \\
\text { day, daily for } 4 \text { weeks. }\end{array}$ & Rat femur & $\begin{array}{l}\text { Cefuroxime decreased callus mechanical } \\
\text { resistance and lowered histological grade. } \\
\text { Cefazolin did not influence studied parameters. }\end{array}$ & $\begin{array}{l}\text { Natividad- } \\
\text { Pedreno et al. } \\
(2016)\end{array}$ \\
\hline $\begin{array}{l}\text { Gentamicin: } 10 \% \text { gentamicin coated } \\
\text { implant. }\end{array}$ & Rat tibia & $\begin{array}{l}\text { Local application of gentamicin did not influence } \\
\text { tibial fracture healing. }\end{array}$ & $\begin{array}{l}\text { Fassbender et al. } \\
\qquad(2013)\end{array}$ \\
\hline $\begin{array}{l}\text { Doxycycline: } 2 \text { and } 10 \mathrm{mg} / \mathrm{kg} \text { per day } \\
\text { for } 7 \text { days. }\end{array}$ & Mouse calvaria & $\begin{array}{l}\text { Doxycycline inhibited osteolysis. Suggestion for } \\
\text { use of doxycycline for treatment or prevention } \\
\text { of wear particle-induced osteolysis and aseptic } \\
\text { loosening. }\end{array}$ & $\begin{array}{l}\text { Zhang et al. } \\
\quad(2007)\end{array}$ \\
\hline $\begin{array}{l}\text { Tetracycline: } 30 \text { mg/graft. } \\
\text { Gentamicin: } 15 \text { mg/graft. }\end{array}$ & Rat calvaria & Antibiotics impaired bone formation. & Kim et al. (2004) \\
\hline $\begin{array}{l}\text { Gentamicin: } 1.5 \mathrm{mg} / \mathrm{kg} \text {, twice per day } \\
\text { for } 3 \text { weeks. Vancomycin: } 25 \mathrm{mg} / \mathrm{kg} \text {, } \\
\text { twice per day for } 3 \text { weeks. }\end{array}$ & Rat calvaria & $\begin{array}{l}\text { Antibiotics had no effects on biomechanical and } \\
\text { radiographic scores. }\end{array}$ & $\begin{array}{l}\text { Haleem et al. } \\
\quad(2004)\end{array}$ \\
\hline $\begin{array}{l}\text { Levofloxacin: } 25 \mathrm{mg} / \mathrm{kg} \text {, } \\
\text { trovafloxacin: } 35 \mathrm{mg} / \mathrm{kg} \text {. Both drugs } \\
\text { were used twice a day for } 3 \text { weeks, } \\
\text { started } 1 \text { week post femoral fracture. }\end{array}$ & Rat femur & $\begin{array}{l}\text { Antibiotic induced less woven bone and more } \\
\text { cartilage in the fracture sites. }\end{array}$ & Perry et al. (2003) \\
\hline $\begin{array}{l}\text { Ciprofloxacin: } 50 \mathrm{mg} / \mathrm{kg} \text {, twice a day } \\
\text { for } 3 \text { weeks, } 1 \text { week post femoral } \\
\text { fracture. }\end{array}$ & Rat femur & $\begin{array}{c}\text { Decreased radiographic results, lowered } \\
\text { torsional strength, and abnormal cartilage } \\
\text { morphology were observed in the treatment } \\
\text { group. }\end{array}$ & $\begin{array}{l}\text { Huddleston et al. } \\
\qquad(2000)\end{array}$ \\
\hline $\begin{array}{l}\text { Quinolones: } 100,350,500,750 \\
\mathrm{mg} / \mathrm{kg} \text { per day for } 5 \text { days. }\end{array}$ & $\begin{array}{l}\text { Rabbit joints: } \\
\text { shoulder, hip, } \\
\text { knee }\end{array}$ & $\begin{array}{l}\text { Drug caused degenerated or hypertrophic } \\
\text { chondrocytes, loss of collagen and } \\
\text { proteoglycan. Effects were not clearly dose- } \\
\text { related. }\end{array}$ & $\begin{array}{l}\text { Gough et al. } \\
\quad(1996)\end{array}$ \\
\hline
\end{tabular}

The negative effect of corticosteroids on bone healing was consistent in the literature, especially if the high doses and/or long treatments were applied. Nonetheless, there is also some evidence that corticosteroids can be used for a short time with appropriate doses if their benefits outweigh their potential side effects.

\section{Effects of non-steroidal anti- inflammatory drugs on Bone Healing}

The inhibitory effect on bone fracture healing is attributable to many NSAIDs, including indomethacin (Brown et al., 2004; Hogevold et al., 1992; Lack et al., 2013), ketorolac (Gerstenfeld et al., 2003), etodolac
(Endo et al., 2002), diclofenac (Bissinger et al., 2016; Krischak et al., 2007), ibuprofen (Kidd et al., 2013; Leonelli et al., 2006), dexketoprofen and meloxicam (Inal et al., 2014), aspirin (Lack et al., 2013), parecoxib (Gerstenfeld et al., 2003), rofecoxib (Leonelli et al., 2006) and celecoxib (Simon \& O'Connor, 2007). Most of these NSAIDs doses were below or comparable to the recommended dosage for treatment of diseases in humans. Only some of these studies used high doses of NSAIDs, i.e., indomethacin at 12.5 $\mathrm{mg} / \mathrm{kg} / \mathrm{day}$, aspirin at $100-300 \mathrm{mg} / \mathrm{kg} /$ day (Lack et al., 2013), and rofecoxib at $8 \mathrm{mg} / \mathrm{kg} /$ day (Leonelli et al., 2006). Impaired fracture healing may be partially due to long-term exposure to drugs, including diclofenac for 21 days (Bissinger et al., 2016), rofecoxib and ibuprofen 
Table 2. In vivo effects of corticosteroids on bone healing

\begin{tabular}{|c|c|c|c|}
\hline Drug and dosage & Animal and bone & Results & References \\
\hline $\begin{array}{l}\text { Prednisolone: } 4 \mathrm{mg} / \mathrm{day} \text { for } 4 \\
\text { weeks, followed by } 2 \mathrm{mg} / \mathrm{day} \text { for } \\
\text { another } 4 \text { weeks. }\end{array}$ & Dog mandible & Prednisolone decreased bone-implant contact. & $\begin{array}{l}\text { Yaghini et al. } \\
\quad \text { (2017) }\end{array}$ \\
\hline $\begin{array}{l}\text { Prednisolone: } 0.5 \mathrm{mg} / \mathrm{kg} \text { per day, } \\
\text { daily for } 21 \text { days. }\end{array}$ & Rat femur & $\begin{array}{l}\text { No significant effect of prednisolone on bone } \\
\text { healing was evident although the absolute values } \\
\text { of mechanical parameters in prednisolone group } \\
\text { were lower in comparison with the control. }\end{array}$ & $\begin{array}{l}\text { Bissinger et al. } \\
\qquad(2016)\end{array}$ \\
\hline $\begin{array}{l}\text { Methylprednisolone: } 20 \mathrm{mg} / \mathrm{kg} \text { per } \\
\text { day, three times on day } 16,15 \text { and } \\
14 \text { pre-surgery. }\end{array}$ & Rabbit femur & $\begin{array}{l}\text { Methylprednisolone induced osteonecrosis, } \\
\text { impaired healing and maturation of bone tissue. }\end{array}$ & Xie et al. (2011) \\
\hline $\begin{array}{l}\text { Prednisone: } 0.02 \mathrm{mg} / \mathrm{kg}, 4 \\
\text { consecutive days started prior to } \\
\text { surgery. }\end{array}$ & Rat femur & Prednisone had no effect on bone healing. & $\begin{array}{l}\text { Aslan et al. } \\
\quad(2005)\end{array}$ \\
\hline $\begin{array}{l}\text { Prednisolone: } 0.35 \mathrm{mg} / \mathrm{kg} \text { per day, } \\
\text { three times a week for } 6 \text { weeks } \\
\text { before surgery. }\end{array}$ & Rabbit ulna & $\begin{array}{l}\text { Prednisolone inhibited bone healing characterized } \\
\text { by a small callus area, low torsional strength. }\end{array}$ & $\begin{array}{l}\text { Luppen et al. } \\
\text { (2002) }\end{array}$ \\
\hline $\begin{array}{l}\text { Dexamethasone: } 0.05 \mathrm{mg} / \mathrm{kg} \text { per } \\
\text { time, twice every day for } 42 \text { days } \\
\text { since surgery. }\end{array}$ & Rabbit spine & $\begin{array}{l}\text { Dexamethasone decreased the rate of bone graft } \\
\text { union. }\end{array}$ & $\begin{array}{l}\text { Sawin et al. } \\
\quad(2001)\end{array}$ \\
\hline $\begin{array}{l}\text { Prednisone: } 0.15 \mathrm{mg} / \mathrm{kg} \text { per day, } \\
60 \text { days before osteotomy until } 6 \\
\text { weeks postosteotomy. }\end{array}$ & Rabbit ulna & Prednisone induced bone loss. & $\begin{array}{l}\text { Bostrom et al. } \\
\qquad(2000)\end{array}$ \\
\hline $\begin{array}{l}\text { Prednisone: } 0.15 \mathrm{mg} / \mathrm{kg} \text { per day, } \\
60 \text { days before osteotomy to } 6 \\
\text { weeks post-surgery. }\end{array}$ & Rabbit ulna & $\begin{array}{l}\text { Prednisone caused lower results in callus size, } \\
\text { radiographic density, bone mineral content and } \\
\text { mechanical strength. }\end{array}$ & $\begin{array}{l}\text { Waters et al. } \\
\quad(2000)\end{array}$ \\
\hline $\begin{array}{l}\text { Methylprednisolone: } 2 \mathrm{mg} / \mathrm{kg}, 4 \\
\text { consecutive days started prior to } \\
\text { surgery. }\end{array}$ & Rat femur & $\begin{array}{c}\text { Methylprednisolone had no inhibitory effect on } \\
\text { bone healing. }\end{array}$ & $\begin{array}{l}\text { Hogevold et al. } \\
\text { (1992) }\end{array}$ \\
\hline $\begin{array}{l}\text { Cortisone: } 10,20 \mathrm{mg} / \mathrm{kg} \text { per day for } \\
14 \text { days. }\end{array}$ & $\begin{array}{l}\text { Rabbit femur and } \\
\text { tibia }\end{array}$ & $\begin{array}{l}\text { Longitudinal bone growth instantly stopped after } \\
\text { the commencement of cortisone administration. } \\
\text { The cartilage was thinned as soon as day } 6 . \text { By } \\
\text { day } 24 \text { extensive destruction of metaphyseal } \\
\text { trabeculae was apparent. }\end{array}$ & $\begin{array}{l}\text { Sissons \& } \\
\text { Hadfield (1955) }\end{array}$ \\
\hline $\begin{array}{l}\text { Cortisone: } 20 \mathrm{mg} / \mathrm{kg} \text { per day for } 21 \\
\text { days. }\end{array}$ & $\begin{array}{l}\text { Rat femur and } \\
\text { tibia }\end{array}$ & $\begin{array}{l}\text { The harmful effect of cortisone on bone growth in } \\
\text { rats was less severe than in rabbits. }\end{array}$ & \\
\hline
\end{tabular}

for 28 days (Leonelli et al., 2006), ketorolac and parecoxib for 35 days (Gerstenfeld et al., 2003), indomethacin, celecoxib for 28,56 or 112 days (Brown et al., 2004). The inhibitory effect of NSAIDs on fracture healing was observed even when the treatment durations and doses were comparable to ordinary prescription, ie., indomethacin at a dose of $2 \mathrm{mg} / \mathrm{kg} / \mathrm{day}$ for 4 days (Hogevold et al., 1992), etodolac at 20 $\mathrm{mg} / \mathrm{kg} / \mathrm{day}$ for 7 days (Endo et al., 2002) and celecoxib at $4 \mathrm{mg} / \mathrm{kg} /$ day for 5 days (Simon \& O'Connor, 2007). 
Although there are a few studies supporting the use of some NSAIDs, such as ketorolac (Cappello et al., 2013; Fracon et al., 2010), paracetamol, etoricoxib (Fracon et al., 2010) during bone healing treatment, there are far more studies reporting the newgative impact of bone healing. Therefore, use of NSAIDs during fracture healing should only be considered when the drugs' benefits over-ride their negative impacts (Table 3).

\section{Effects of anticoagulants on Bone Healing}

The use of anticoagulants for prevention of thrombosis and pulmonary embolism in traumatic and orthopedic cases is common (Prodinger et al., 2016). Anticoagulants may elicit inhibitory effects on osteoblast formation, and may intensify bone resorption (Kapetanakis et al., 2015). Enoxaparin has been found to exert a negative effect on fracture healing in rabbit ribs (Street et al., 2000, whereas this drug does not influence bone healing of rat femur (Curcelli et al., 2005; Demirtas et al., 2013; Say et al., 2013). Bone fracture healing is independent of many anticoagulants, including heparin (Curcelli et al., 2005; Erli et al., 2006), dalteparin (Erli et al., 2006; Hak et al., 2006; Say et al., 2013), certoparin (Erli et al., 2006), nadroparin (Say et al., 2013), and rivaroxaban (Demirtas et al., 2013). Rivaroxaban increased the callus volume but decreased bone mineral density resulting in unchanged mechanical parameters (Kluter et al., 2015; Prodinger et al., 2016). It appears that negative effects of anticoagulants on bone fracture healing is still minimal. A definitive conclusion of the effect of anticoagulants on bone healing is impossible discern due to the differences in drugs used, time of drug exposure, drug doses, animal models, fractured bones, time of evaluation and means of evaluation. Therefore, these drugs are still a gold standard for prevention of thrombosis and pulmonary embolism in animals with bone fracture(s). Nevertheless, more well-designed studies are required to determine the true effects of anticoagulants on bone fracture healing (Table 4).

\section{Effects of chemotherapeutic agents on Bone Healing}

Chemotherapeutic agents are commonly prescribed for treatment of cancers and chronic inflammation. High doses are recommended for oncological treatment, and low doses are for chronic inflammation (Cavalcanti et al., 2014). Results show that these drugs are also significantly involved in the bone healing process. Fracture healing was completely prevented by angiogenesis inhibitor TNP-470 via suppression of both intramembranous and endochondral ossifications (Hausman et al., 2001). Histological and radiographical

Table 3. In vivo effects of NSAIDs on bone healing

\begin{tabular}{|c|c|c|c|}
\hline Drug and dosage & $\begin{array}{l}\text { Animal and } \\
\text { bone }\end{array}$ & Results & References \\
\hline Diclofenac: $5 \mathrm{mg} / \mathrm{kg}$ per day for 21 days. & Rat femur & $\begin{array}{l}\text { Diclofenac decreased stiffness, trabecular } \\
\text { thickness and callus volume. }\end{array}$ & $\begin{array}{l}\text { Bissinger et } \\
\text { al. (2016) }\end{array}$ \\
\hline $\begin{array}{l}\text { Dexketoprofen: } 0.98 \mathrm{mg} / \mathrm{kg} \text { per half a day, } \\
\text { meloxicam: } 0.2 \mathrm{mg} / \mathrm{kg} \text { per day, diclofenac: } \\
1 \mathrm{mg} / \mathrm{kg} \text { per day. All drugs were used for } 10 \\
\text { days. }\end{array}$ & Rat fibula & $\begin{array}{l}\text { Dexketoprofen and meloxicam inhibited bone } \\
\text { fracture healing while diclofenac did not. }\end{array}$ & $\begin{array}{l}\text { Inal et al. } \\
(2014)\end{array}$ \\
\hline $\begin{array}{l}\text { Indomethacin: } 12.5 \mathrm{mg} / \mathrm{kg} \text { per day. Aspirin: } \\
2.7 \mathrm{mg} / \mathrm{kg} \text { per day, } 10 \mathrm{mg} / \mathrm{kg} \text { per day, } 50 \\
\mathrm{mg} / \mathrm{kg} \text { twice per day, } 100 \mathrm{mg} / \mathrm{kg} \text { three times } \\
\text { per day. All drugs were used for } 8 \text { weeks. }\end{array}$ & Rabbit ulna & $\begin{array}{l}\text { Aspirin at } 10 \mathrm{mg} / \mathrm{kg} \text { and } 100 \mathrm{mg} / \mathrm{kg} \text {, and } \\
\text { indomethacin decreased bone healing. }\end{array}$ & $\begin{array}{l}\text { Lack et al. } \\
\quad(2013)\end{array}$ \\
\hline
\end{tabular}




\begin{tabular}{l} 
Drug and dosage \\
\hline $\begin{array}{l}\text { Ketorolac: } 5 \mathrm{mg} / \mathrm{kg} \text { per day for either } 7,14 \\
\text { or } 21 \text { days. }\end{array}$
\end{tabular}
or 21 days.

Ibuprofen: $30 \mathrm{mg} / \mathrm{kg}$ per day for either 2, 4, or 6 weeks.

Paracetamol: $80 \mathrm{mg} / \mathrm{kg}$ per day. Ketorolac: $4 \mathrm{mg} / \mathrm{kg}$ per day. Etoricoxib: $10 \mathrm{mg} / \mathrm{kg}$ per day. All drugs were daily used, for 2 weeks since surgery.

Diclofenac: $5 \mathrm{mg} / \mathrm{kg}$ per day for either 7 or 21 days.

Celecoxib: 2, 4, $8 \mathrm{mg} / \mathrm{kg}$ per day for 15 days, started $4 \mathrm{~h}$ post fracture.

$4 \mathrm{mg} / \mathrm{kg}$ per day for either $5,10,21$, or 28 days started $4 \mathrm{~h}$ postfracture.

Rat tibia

$4 \mathrm{mg} / \mathrm{kg}$ per day, started at 5 days prefracture, or $1,7,14$ days postfracture, until day 28.

Rofecoxib: $8 \mathrm{mg} / \mathrm{kg}$ per day for 4 weeks. Ibuprofen: $30 \mathrm{mg} / \mathrm{kg}$ per day for 4 weeks.

Indomethacin: $1 \mathrm{mg} / \mathrm{kg}$ per day for $4,8,12$ weeks. Celecoxib: $3 \mathrm{mg} / \mathrm{kg}$ per day for $4,8,12$ weeks.

Ketorolac: $4 \mathrm{mg} / \mathrm{kg}$ per day, for either 21 or 35 days. Parecoxib: 0.3 and $1.5 \mathrm{mg} / \mathrm{kg}$ per day for either 21 or 35 days.

Etodolac: $20 \mathrm{mg} / \mathrm{kg}$ per day for 3 weeks started from surgery until day 21, or for 1 week started from surgery until day 7 , or for 1 week started from day 14 until day 21 .

Indomethacin: $2 \mathrm{mg} / \mathrm{kg}, 4$ consecutive days started prior to surgery.

bone

Rat tibia

Rat ulna

Rat tooth

Rat femur

Rat femur

Rat femur

\section{Animal and} No effect of ketorolac on bone healing was
seen at any time point of evaluation.

References

Results
No effect of ketorolac on bone healing was
seen at any time point of evaluation.

Treatment of ibuprofen decreased bone resorption and reduced bone formation which resulted in lower length and area of lamellar bone.

\section{Cappello et} al. (2013)

Kidd et al. No drug had an inhibitory effect on volume fraction of trabecular bone.

Fracon et al. (2010)

Histomorphometric evaluation revealed that long-term instead of short-term treatment of diclofenac resulted in a higher amount of cartilage and less bone.

Krischak et al. (2007)

Use of celecoxib for 15 days at any studied doses increased the rate of bone nonunion. $A$ dose of $4 \mathrm{mg} / \mathrm{kg}$ for 5 days decreased the mechanical strength and increased the nonunion rate. No harmful effect was detected when the use of celecoxib was commenced at $5^{\text {th }}$ day prior to or at $14^{\text {th }}$ day after operation.

Incidence of nonunion in rofecoxib and ibuprofen groups was higher than that in the control group.

Leonelli et al.

Both indomethacin and celecoxib delayed bone healing at 4 and 8 weeks post operation.

Brown et al. (2004)

Both parecoxib and ketorolac impaired bone healing, but ketorolac expressed more harmful effects.

Gerstenfeld et al. (2003)

In all groups of treatment, radiographic and mechanical testing showed lower scores which predisposed fractures to delayed healing.

Endo et al. (2002)

Indomethacin impaired bone healing. This
Hogevold et al. (1992) effect was more severe when fracture healed under unstable condition. 
assessments revealed that doxorubicin and cisplatin affect both quantity and quality of the healing bone of rabbit segmental radial diaphyseal fractures (Morcuende et al., 2004). Even a single dose of doxorubicin at the time of surgery significantly inhibited the process of spinal fusion (Tortolani et al., 2004). Similarly, a single dose of methotrexate at either 30 or $250 \mathrm{mg}$ at surgery decreases bone formation resulting in impaired bone healing (Cavalcanti et al., 2014; Satoh et al., 2011). By contrast, methotrexate at a low dose (3mg every week, for 1-4 weeks) did not delay fracture healing process (Cavalcanti et al., 2014; Satoh et al., 2011). The effect of chemotherapeutic agents on bone healing may depend on drug types, and the doses of drugs. Although the effects of chemotherapeutic agents on bone healing are apparent, their use in some cases, including cancer, can not be avoided. In such cases, adjunctive treatment such as growth factors may be considered to reduce the drugs' negative effects and normalize bone healing process (Table 5).

Table 4. In vivo effects of anticoagulants on bone healing

\begin{tabular}{|c|c|c|c|}
\hline Drug and dosage & $\begin{array}{l}\text { Animal and } \\
\text { bone }\end{array}$ & Results & References \\
\hline $\begin{array}{l}\text { Rivaroxaban: } 600 \mathrm{ppm} / \mathrm{g} \text { of } \\
\text { medicated food, enoxaparin: } 100 \\
\text { IU/kg twice every day for } 21 \text { days. }\end{array}$ & Rat femur & $\begin{array}{l}\text { Rivaroxaban increased callus volume which } \\
\text { corresponded to reduced bone density. } \\
\text { Treatment of both rivaroxaban and enoxaparin } \\
\text { resulted in enlarged callus surface, trabecular } \\
\text { thickness, and degree of bone anisotropy. } \\
\text { Biomechanical characteristics were not } \\
\text { influenced by any drugs administered. }\end{array}$ & $\begin{array}{l}\text { Prodinger et } \\
\text { al. (2016) }\end{array}$ \\
\hline $\begin{array}{l}\text { Rivaroxaban: } 3 \mathrm{mg} / \mathrm{kg} \text { per day for } \\
\text { either } 28 \text { or } 49 \text { days. }\end{array}$ & Rat femur & $\begin{array}{c}\text { Rivaroxaban increased callus volume and } \\
\text { induced a marginal increase in bone mineral } \\
\text { density, but torsional rigidity was not affected by } \\
\text { the treatment. }\end{array}$ & $\begin{array}{l}\text { Klüter et al. } \\
\quad(2015)\end{array}$ \\
\hline $\begin{array}{l}\text { Enoxaparin: } 1000 \text { anti Xa IU/kg per } \\
\text { day, rivaroxaban: } 3 \mathrm{mg} / \mathrm{kg} \text { per day, } \\
\text { fondaparinux: } 0.2 \mathrm{mg} / \mathrm{kg} \text { per day } \\
\text { for } 21 \text { days. }\end{array}$ & Rat femur & $\begin{array}{c}\text { No effects of enoxaparin, rivaroxaban and } \\
\text { fondaparinux on fracture healing was noticed } \\
\text { via radiographic and histopathological } \\
\text { examinations. }\end{array}$ & $\begin{array}{l}\text { Demirtas et } \\
\text { al. (2013) }\end{array}$ \\
\hline $\begin{array}{l}\text { Fondaparinux: } 1 \mathrm{mg} / \mathrm{kg} \text { per day, } \\
\text { dalteparin: } 140 \mu \mathrm{g} / \mathrm{kg} \text { per day, } \\
\text { nadroparin: } 200 \mu \mathrm{g} / \mathrm{kg} \text { per day, } \\
\text { enoxaparin: } 1 \mathrm{mg} / \mathrm{kg} \text { per day for } 28 \\
\text { days. }\end{array}$ & Rat femur & $\begin{array}{l}\text { Fondaparinux had a stimulatory effect on bone } \\
\text { healing. Dalteparin, nadroparin, and enoxaparin } \\
\text { had no effect on fracture healing. }\end{array}$ & $\begin{array}{l}\text { Say et al. } \\
\text { (2013) }\end{array}$ \\
\hline $\begin{array}{l}\text { Heparin: } 133 \mathrm{IE} / \mathrm{kg} \text { per day, } \\
\text { certoparin: } 50 \text { anti-Xa-units } / \mathrm{kg} \mathrm{per} \\
\text { day, dalteparin: } 50 \text { anti-Xa-units } / \mathrm{kg} \\
\text { per day for } 42 \text { days. }\end{array}$ & Rabbit femur & $\begin{array}{l}\text { Histological examination revealed that there } \\
\text { was no significant effect of anticoagulants on } \\
\text { bone healing. }\end{array}$ & $\begin{array}{l}\text { Erli et al. } \\
\text { (2006) }\end{array}$ \\
\hline $\begin{array}{l}\text { Dalteparin: } 70 \text { unit/kg per day for } \\
14 \text { days. }\end{array}$ & Rat femur & $\begin{array}{l}\text { Dalteparin did not alter radiographic, } \\
\text { histological and, mechanical results. }\end{array}$ & $\begin{array}{l}\text { Hak et al. } \\
\quad(2006)\end{array}$ \\
\hline $\begin{array}{l}\text { Heparin: } 400 \mathrm{IU} / \mathrm{kg} \text { per day, } \\
\text { enoxaparin: } 2 \mathrm{mg} / \mathrm{kg} \text { per day for } 28 \\
\text { days. }\end{array}$ & Rat femur & $\begin{array}{l}\text { Heparin and enoxaparin had no effect on } \\
\text { histological and mechanical grades. }\end{array}$ & $\begin{array}{l}\text { Curcelli et al. } \\
\qquad(2005)\end{array}$ \\
\hline $\begin{array}{l}\text { Enoxaparin: } 2 \mathrm{mg} / \mathrm{kg} \text { per day for } \\
\text { either } 3,7,14 \text {, or } 21 \text { days. }\end{array}$ & Rabbit rib & $\begin{array}{l}\text { Inhibitory effect of enoxaparin on bone healing } \\
\text { was detected at all times of evaluation. }\end{array}$ & $\begin{array}{l}\text { Street et al. } \\
\quad(2000)\end{array}$ \\
\hline
\end{tabular}


Table 5. In vivo effects of chemotherapetic agents on bone healing

\begin{tabular}{|c|c|c|c|}
\hline Drug and dosage & $\begin{array}{l}\text { Animal and } \\
\text { bone }\end{array}$ & Results & References \\
\hline $\begin{array}{l}\text { Methotrexate: } 3 \mathrm{mg} \text { per week for } 1,2,4 \text { weeks or a } \\
\text { single dose of } 30 \mathrm{mg} / \mathrm{kg} \text {. }\end{array}$ & $\begin{array}{c}\text { Rat } \\
\text { mandible }\end{array}$ & $\begin{array}{l}\text { High dose of methotrexate impaired } \\
\text { bone healing characterized by } \\
\text { decreased bone formation. }\end{array}$ & $\begin{array}{l}\text { Cavalcanti et } \\
\text { al. (2014) }\end{array}$ \\
\hline $\begin{array}{l}\text { Methotrexate: High dose: } 250 \mathrm{mg} / \mathrm{kg} \text { on the day of } \\
\text { surgery. Low dose: } 3 \mathrm{mg} / \mathrm{kg} \text { per week for } 4 \text { weeks } \\
\text { before surgery until either } 1 \text { or } 4 \text { weeks after surgery. }\end{array}$ & Rat femur & $\begin{array}{l}\text { High dose rather than low dose of } \\
\text { methotrexate significantly impaired } \\
\text { bone healing. }\end{array}$ & $\begin{array}{l}\text { Satoh et al. } \\
\quad(2011)\end{array}$ \\
\hline Doxorubicin: $2.5 \mathrm{mg} / \mathrm{kg}$ at surgery. & $\begin{array}{l}\text { Rabbit } \\
\text { spine }\end{array}$ & $\begin{array}{l}\text { Bone fusion rate was reduced in the } \\
\text { treatment group. }\end{array}$ & $\begin{array}{l}\text { Tortolani et al. } \\
\quad(2004)\end{array}$ \\
\hline $\begin{array}{l}2.5 \mathrm{mg} / \mathrm{kg} \text { of both doxorubicin and cisplatin three } \\
\text { times, i.e. at } 4 \text { days prior to } 7 \text { and } 14 \text { days after } \\
\text { operation. }\end{array}$ & $\begin{array}{l}\text { Rabbit } \\
\text { radius }\end{array}$ & $\begin{array}{l}\text { Chemotherapy decreased bone area } \\
\text { and bone density. }\end{array}$ & $\begin{array}{l}\text { Morcuende et } \\
\text { al. (2004) }\end{array}$ \\
\hline $\begin{array}{l}\text { Angiogenesis inhibitor TNP-470: } 30 \mathrm{mg} / \mathrm{kg} \text { per day, } \\
\text { every other day for either } 7,14 \text {, or } 21 \text { days. }\end{array}$ & Rat femur & $\begin{array}{l}\text { Antiangionic drug prevented bone } \\
\text { formation. }\end{array}$ & $\begin{array}{l}\text { Hausman et al. } \\
\text { (2001) }\end{array}$ \\
\hline
\end{tabular}

\section{Effects of Anesthetics on Bone Healing}

Anesthetics are routinely utilized in many surgical procedures, particularly in orthopedics. Besides their anesthetic properties, they also have anti-inflammatory characteristics. Isoflurane reduces the systemic release of TNF$\alpha$ and IL-1 $\beta$ (Flondor et al., 2008). TNF- $\alpha$, IL-6 and IL-8 production from human whole blood culture was also suppressed by ketamine (Kawasaki et al., 1999). Furthermore, ketamine lowers TNF- $\alpha$ activity and mortality of carrageenan-sensitized endotoxemic rats (Koga et al., 1994), and decreases TNF- $\alpha$ production in LPS-induced endotoxemia in mice (Taniguchi et al., 2001). Interestingly, ketamine did not exert those effects if entotoxins were absent. The mechanism of ketamine-induced antiinflammation is believed to be partially due to its effect on cyclooxygenase activity (Suliburk et al., 2005). Furthermore, in rats, the antiinflammatory effect of ketamine was seen only at sub-anesthetic dosages $(0.5-5 \mathrm{mg} / \mathrm{kg})$, whereas at high dosage $(50 \mathrm{mg} / \mathrm{kg})$ it enhanced the TNF- $\alpha$ production (Sun et al., 2004). Although there are no direct results showing that anesthetics influence bone fracture healing, their effects on inflammatory cytokines are apparent. The bone healing process is, on the other hand, involved in the inflammatory mechanism. Therefore, it may be hypothesized that some anesthetics such as isoflurane and ketamine may influence bone fracture healing (Histing et al., 2011). Because the true effect of anesthetics on bone healing has not been determined to date, their use still contributes to the success of millions of orthopedics procedures worldwide.

\section{Conclusions}

This overview showed that the course of bone healing may be influenced by several drugs and treatment regimes. However, the negative effects of several antibiotics and steroids on bone healing may be due to their high doses and/or long treatments because such effects were absent when normal doses and treatment periods were applied. The use of such drugs in partients with bone fracture(s) is reasonable if the normal doses and durations of treatments are followed. In contrast, many non-steroidal inflammatory drugs may affect bone healing even at their standard treatment usage. Hence, these drugs should not 
be prescribed for orthopedic animals treatments. There is a large body of research demonstrating negative effects of chemotherapy agents on bone healing. However, a low dose of methotrexate may be appropriate for animals that have cancer or chronic inflammation and acquire bone fracture(s). More well-designed studies are needed before a conclusion on the effect of anticoagulants and anesthetics on bone healing process can be ascertained. The use of some drugs is inevitable during the treatment of bone fractures, therefore, understandings of their effects on bone healing are imperative to increase the chances of successful treatments.

\section{References}

Aslan M., Simsek G. \& Yildirim U. (2005). Effects of short-term treatment with systemic prednisone on bone healing: an experimental study in rats. Dental Traumatology. 21(4): 222-225.

Bissinger O., Kreutzer K., Götz C., Hapfelmeier A., Pautke C., Vogt S., Wexel G., Wolff K. D., Tischer T. \& Prodinger P. M. (2016). A biomechanical, microcomputertomographic and histological analysis of the influence of diclofenac and prednisolone on fracture healing in vivo. BMC Musculoskeletal Disorders. 17(1): 383 .

Bostrom M. P., Gamradt S. C., Asnis P., Vickery B., Hill E., Avnur Z. \& Waters R. V. (2000). Parathyroid hormone-related protein analog RS-66271 is an effective therapy for impaired bone healing in rabbits on corticosteroid therapy. Bone. 26(5): 437-442.

Brown K. M., Saunders M. M., Kirsch T., Donahue H. J. \& Reid J. S. (2004). Effect of COX-2-specific inhibition on fracture-healing in the rat femur. The Journal of Bone and Joint Surgery. 86A(1): 116-123.

Cappello T., Nuelle J. A., Katsantonis N., Nauer R. K., Lauing K. L., Jagodzinski J. E. \& Callaci J. J. (2013). Ketorolac administration does not delay early fracture healing in a juvenile rat model: a pilot study. Journal of Pediatric Orthopaedics. 33(4): 415-421.

Cavalcanti S. C., Correa L., Mello S. B. \& Luz J. G. (2014). The effect of methotrexate on the bone healing of mandibular condylar process fracture: an experimental study in rats. Journal of Cranio-Maxillofacial Surgery. 42(7): 1133-1139.

Curcelli E. C., Müller S. S., Ueda A. K., Padovani C. R., Maffei F. H. \& Hossne W. S. (2005). Effect of heparinsodium and enoxaparin on rats tibial fracture healing: clinical, anatomopathological, and biomechanical approach. Acta Ortopédica Brasileira. 13(1): 13-16.

Demirtas A., Azboy I., Bulut M., Ucar B. Y., Alabalik U. \& Necmioglu N. S. (2013). Investigation of the effects of Enoxaparin, Fondaparinux, and Rivaroxaban used in thromboembolism prophylaxis on fracture healing in rats. European Review for Medical and Pharmacological Sciences. 17(14): 1850-1856.

Endo K., Sairyo K., Komatsubara S., Sasa T., Egawa H., Yonekura D., Adachi K., Ogawa T., Murakami R. \& Yasui N. (2002). Cyclooxygenase-2 inhibitor inhibits the fracture healing. Journal of Physiological Anthropology and Applied Human Science. 21(5): 235-238.

Erli H., Melchert M. \& Rüger M. (2006). The effect of lowdosed unfractioned and low-molecular weight heparins on bone healing in vivo. The Internet Journal of Orthopedic Surgery. 3(2). DOI: 10.5580/1f1d.

Fassbender M., Minkwitz S., Kronbach Z., Strobel C., Kadow-Romacker A., Schmidmaier G. \& Wildemann B. (2013). Local gentamicin application does not interfere with bone healing in a rat model. Bone. 55(2): 298-304.

Flondor M., Hofstetter C., Boost K. A., Betz C., Homann M. \& Zwissler B. (2008). Isoflurane inhalation after induction of endotoxemia in rats attenuates the systemic cytokine response. European Surgical Research. 40(1): 1-6.

Fracon R.N., Teofilo J. M., Moris I. C. \& Lamano T. (2010). Treatment with paracetamol, ketorolac or etoricoxib did not hinder alveolar bone healing: a histometric study in rats. Journal of Applied Oral Science. 18(6): 630-634.

Gerstenfeld L. C., Thiede M., Seibert K., Mielke C., Phippard D., Svagr B., Cullinane D. \& Einhorn T. A. (2003). Differential inhibition of fracture healing by non-selective and cyclooxygenase- 2 selective nonsteroidal anti-inflammatory drugs. Journal of Orthopaedic Research. 21(4): 670-675.

Gough A., Johnson R., Campbell E., Hall L., Tylor J., Carpenter A., Black W., Basrur P. K., Baragi V. M., Sigler R. \& Metz A. (1996). Quinolone arthropathy in immature rabbits treated with the fluoroquinolone, PD 117596. Experimental and Toxicologic Pathology. 48(4): 225-232.

Hak D. J., Stewart R. L. \& Hazelwood S. J. (2006). Effect of low molecular weight heparin on fracture healing in a stabilized rat femur fracture model. Journal of Orthopaedic Research. 24(4): 645-652.

Haleem A. A., Rouse M. S., Lewallen D. G., Hanssen A. D., Steckelberg J. M. \& Patel R. (2004). Gentamicin and vancomycin do not impair experimental fracture healing. Clinical Orthopaedics and Related Research. 427: 22-24.

Hausman M. R., Schaffler M. B. \& Majeska R. J. (2001). Prevention of fracture healing in rats by an inhibitor of angiogenesis. Bone. 29(6): 560-564.

Histing T., Garcia P., Holstein J. H., Klein M., Matthys R., Nuetzi R., Steck R., Laschke M. W., Wehner T., Bindl R., Recknagel S., Stuermer E. K., Vollmar B., 
Wildemann B., Lienau J., Willie B., Peters A., Ignatius A., Pohlemann T., Claes L. \& Menger M. D. (2011). Small animal bone healing models: standards, tips, and pitfalls results of a consensus meeting. Bone. 49(4): 591-599.

Hogevold H. E., Grogaard B. \& Reikeras O. (1992). Effects of short-term treatment with corticosteroids and indomethacin on bone healing A mechanical study of osteotomies in rats. Acta Orthopaedica Scandinavica. 63(6): 607-611.

Huddleston P. M., Steckelberg J. M., Hanssen A. D., Rouse M. S., Bolander M. E. \& Patel R. (2000). Ciprofloxacin inhibition of experimental fracture healing. The Journal of Bone and Joint Surgery. 82(2): 161-173.

Inal S., Kabay S., Cayci M. K., Kuru H. I., Altikat S., Akkas G. \& Deger A. (2014). Comparison of the effects of dexketoprofen trometamol, meloxicam and diclofenac sodium on fibular fracture healing, kidney and liver: an experimental rat model. Injury. 45(3): 494-500.

Jahangir A., Nunley R. M., Mehta S. \& Sharan A. (2008). Bone-graft substitutes in orthopaedic surgery American Academy of Orthopaedics Surgeons.[online]. Retrieved from http://wwwaaos org/news/aaosnow/jan08/reimbursement2asp on November 15, 2017.

Kapetanakis S., Nastoulis E., Demesticha T. \& Demetriou T. (2015). The effect of low molecular weight heparins on fracture healing. The Open Orthopaedics Journal. 9: 226-236.

Kawasaki T., Ogata M., Kawasaki C., Ogata J., Inoue Y. \& Shigematsu A. (1999). Ketamine suppresses proinflammatory cytokine production in human whole blood in vitro. Anesthersia and Analgesia. 89(3): 665669.

Kidd L. J., Cowling N. R., Wu A. C., Kelly W. L. \& Forwood M. R. (2013). Selective and non-selective cyclooxygenase inhibitors delay stress fracture healing in the rat ulna. Journal of Orthopaedic Research. 31(2): 235-242.

Kim S. G., Chung T. Y., Kim M. S. \& Lim S. C. (2004). The effect of high local concentrations of antibiotics on demineralized bone induction in rats. Journal of Oral and Maxillofacial Surgery. 62(6): 708-713.

Klüter T., Weuster M., Brüggemann S., Menzdorf L., Oestern S. F., Steubesand N., Acil Y., Pufe T., Varoga D., Seekamp A. \& Lippross S. (2015). Rivaroxaban does not impair fracture healing in a rat femur fracture model: an experimental study. BMC Musculoskeletal Disorders. 16(79). DOI: 10.1186/s12891-015-0502-9.

Koga K., Ogata M., Takenaka I., Matsumoto T. \& Shigematsu A. (1994). Ketamine suppresses tumor necrosis factor-alpha activity and mortality in carrageenan-sensitized endotoxin shock model. Circulatory Shock. 44(3): 160-168.

Krischak G. D., Augat P., Sorg T., Blakytny R., Kinzl L., Claes L. \& Beck A. (2007). Effects of diclofenac on periosteal callus maturation in osteotomy healing in an animal model. Archives of Orthopaedic and Trauma Surgery. 127(1): 3-9.

Lack W. D., Fredericks D., Petersen E., Donovan M., George M., Nepola J., Smucker J. \& Femino J. E. (2013). Effect of aspirin on bone healing in a rabbit ulnar osteotomy model. The Journal of Bone and Joint Surgery. 95(6): 488-496.

Leonelli S. M., Goldberg B. A., Safanda J., Bagwe M. R., Sethuratnam S. \& King S. J. (2006). Effects of a cyclooxygenase-2 inhibitor (rofecoxib) on bone healing. American Journal of Orthopedics. 35(2): 7984

Luppen C. A., Blake C. A., Ammirati K. M., Stevens M. L., Seeherman H. J., Wozney J. M. \& Bouxsein M. L. (2002). Recombinant human bone morphogenetic protein-2 enhances osteotomy healing in glucocorticoidtreated rabbits. Journal of Bone and Mineral Research. 17(2): 301-310

Morcuende J. A., Gomez P., Stack J., Oji G., Martin J., Fredericks D. C. \& Buckwalter J. A. (2004). Effect of chemotherapy on segmental bone healing enhanced by rhBMP-2. Archive of The Iowa Orthopaedic Journal. 24: $36-42$.

Natividad-Pedreno M., Nunez-Chia A., Cobo-Valenzuela N., Alcantara-Martos T., Carrascal M. T. \& DelgadoMartinez A. D. (2016). Effect of cefazolin and cefuroxime on fracture healing in rats. Injury. 47(3): S3-S6.

Perry A. C., Prpa B., Rouse M. S., Piper K. E., Hanssen A. D., Steckelberg J. M. \& Patel R. (2003). Levofloxacin and trovafloxacin inhibition of experimental fracturehealing. Clinical Orthopaedics and Related Research. 414: 95-100.

Porter J. R., Ruckh T. T. \& Popat K. C. (2009). Bone tissue engineering: a review in bone biomimetics and drug delivery strategies. Biotechnology Progress. 25(6): 1539-1560.

Prodinger P. M., Burgkart R., Kreutzer K., Liska F., Pilge H., Schmitt A., Knodler M., Holzapfel B. M., Hapfelmeier A., Tischer T. \& Bissinger O. (2016). Does anticoagulant medication alter fracture-healing? A morphological and biomechanical evaluation of the possible effects of rivaroxaban and enoxaparin using a rat closed fracture model. Public Library of Science One. 11(7): e0159669.

Satoh K., Mark H., Zachrisson P., Rydevik B., Byrod G., Kikuchi S., Konno S. \& Sekiguchi M. (2011). Effect of methotrexate on fracture healing. Fukushima Journal of Medical Science. 57(1): 11-18.

Sawin P. D., Dickman C. A., Crawford N. R., Melton M. S., Bichard W. D. \& Sonntag V. K. (2001). The effects of dexamethasone on bone fusion in an experimental model of posterolateral lumbar spinal arthrodesis. Journal of Neurosurgery. 94(1): 76-81.

Say F., İltar S., Alemdaroğlu K. B., Özel İ., Aydoğan N. H. \& Gönültaş M. (2013). The effect of various types low 
molecular weight heparins on fracture healing. Thrombosis Research. 131(3): e114-e119.

Simon A. M. \& O'Connor J. P. (2007). Dose and timedependent effects of cyclooxygenase-2 inhibition on fracture-healing. The Journal of Bone and Joint Surgery. 89(3): 500-511.

Sissons H. A. \& Hadfield G. J. (1955). The influence of cortisone on the structure and growth of bone. Journal of Anatomy. 89(1): 69-78.

Street J. T., McGrath M., O'Regan K., Wakai A., McGuinness A. \& Redmond H. P. (2000). Thromboprophylaxis using a low molecular weight heparin delays fracture repair. Clinical Orthopaedics and Related Research. 381: 278-289.

Strickland D. (2014). Wearing your seat belt costs you nothing but not wearing one certainly will.[online]. Retrieved from http://www.besmartridesafe.com/ on June 9, 2018.

Suliburk J. W., Helmer K. S., Gonzalez E. A., Robinson E. K. \& Mercer D. W. (2005). Ketamine attenuates liver injury attributed to endotoxemia: role of cyclooxygenase-2. Surgery. 138(2): 134-140.

Sun J., Li F., Chen J. \& Xu J. (2004). Effect of ketamine on NF-kappa B activity and TNF-alpha production in endotoxin-treated rats. Annals of Clinical and Laboratory Science. 34(2): 181-186.

Taniguchi T., Shibata K. \& Yamamoto K. (2001). Ketamine inhibits endotoxin-induced shock in rats. Anesthesiology. 95(4): 928-932.
Tortolani P. J., Park A. E., Louis-Ugbo J., Attallah-Wasef E. S., Kraiwattanapong C., Heller J. G., Boden S. D. \& Yoon S. T. (2004). The effects of doxorubicin (adriamycin) on spinal fusion: an experimental model of posterolateral lumbar spinal arthrodesis. The Spine Journal. 4(6): 669-674.

Vnuk D., Pirkic B., Maticic D., Radisic B., Stejskal M., Babic T., Kreszinger M. \& Lemo N. (2004). Feline high-rise syndrome: 119 cases (1998-2001). Journal of Feline Medicine and Surgery. 6(5): 305-312.

Waters R. V., Gamradt S. C., Asnis P., Vickery B. H., Avnur Z., Hill E. and Bostrom M. (2000). Systemic corticosteroids inhibit bone healing in a rabbit ulnar osteotomy model. Acta Orthopaedica Scandinavica. 71(3): 316-321.

Xie X. H., Wang X. L., Zhang G., Liu Z., Yao D., Hung L. K., Hung V. W. \& Qin L. (2011). Impaired bone healing in rabbits with steroid-induced osteonecrosis. Journal of Bone and Joint Surgery. 93(4): 558-565.

Yaghini J., Abed A. M., Izadi M., Birang R., Torabinia N. \& Tavakoli M. (2017). Effect of short-term steroid use (Prednisolone) on bone healing around implants: An experimental study on dogs. Journal of Oral Health and Dental Management. 16(2): 1-4.

Zhang C., Tang T. T., Ren W. P., Zhang X. L. \& Dai K. R. (2007). Inhibiting wear particles-induced osteolysis with doxycycline. Acta Pharmacologica Sinica. 28(10): 1603-1610. 